\title{
Thermal requirements and age-specific life tables of cowpea aphids in cowpea under natural field conditions
}

\author{
Exigências térmicas e tabelas de expectativa de vida específicas \\ para pulgão preto em feijão-caupi sob condições naturais de campo
}

\author{
José Edmir Girão Filho1* (D), Luiz Evaldo de Moura Pádua' ${ }^{(D)}$, Gilson Lages Fortes Portela² (D), \\ Francinalva de Morais Sousa ${ }^{1}$
}

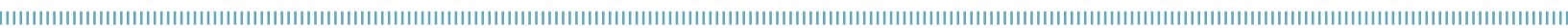

\begin{abstract}
Thermal requirements and life tables of insects are important tools in the ecological management of pests. Thus, this study aimed to construct age-specific life tables for Aphis craccivora at different times of the year and, based on their thermal requirements, predict the occurrence of adults under field conditions. To that end, aphids of known age were kept in cages over cowpea plants at different times of the year - November 2016 and March, April, and June 2017 — at the Agricultural Sciences Center of the Federal University of Piauí. Parameters of development, fertility, and mortality were observed daily, allowing us to construct age-specific life tables, as well as an accumulated degree-day model to predict adult occurrence. The time of year affected the first and second stages of development of the cowpea aphid, the nymphal and reproductive periods, longevity, the biological cycle, the number of nymphs produced per female, the daily production of nymphs per female, life expectancy $\left(\mathrm{e}_{\mathrm{x}}\right)$, and survival $\left(\mathrm{L}_{\mathrm{x}}\right)$. However, the fertility life tables showed significant differences only in the net reproduction rate $\left(\mathrm{R}_{0}\right)$. The proposed degreeday model reached an accuracy of one day or more than the observed value, with a maximum error of $12.9 \%$. We concluded that the proposed model is adequate to predict the occurrence of adults in the field and that the population parameters of A. craccivora in cowpea are negatively affected during November and positively affected in June.
\end{abstract}

KEYWORDS: Aphis craccivora; Vigna unguiculata; insect ecology; temperature; thermal constant.
RESUMO: As exigências térmicas dos insetos, bem como as tabelas de vida, são ferramentas importantes para o manejo ecológico de pragas. Assim, objetivou-se elaborar as tabelas de expectativa de vida específicas para Aphis craccivora em diferentes épocas do ano e, como base em suas exigências térmicas, prever a ocorrência de adultos em condiçôes de campo. Para isso, pulgóes de idade conhecida foram mantidos em gaiolas sobre feijão-caupi em diferentes épocas do ano, novembro de 2016 e março, abril e junho de 2017, no Centro de Ciências Agrárias da Universidade Federal do Piauí. Os parâmetros de desenvolvimento, fertilidade e mortalidade foram observados diariamente, permitindo a elaboraçáo das tabelas de expectativa de vida, bem como a obtenção dos Graus-dia acumulados para a predição de ocorrência adulta. A época do ano afetou significativamente o primeiro e o segundo estádio de desenvolvimento do pulgáo-pretodo-caupi, bem como os períodos ninfal e reprodutivo, a longevidade, ciclo biológico, o número de ninfas produzidas por fêmea e a produção diária de ninfas por fêmea, bem como a expectativa de vida $\left(e_{x}\right)$ e sobrevivência $\left(L_{x}\right)$. No entanto, para as tabelas de vida de fertilidade, só houve diferenças estatísticas para a taxa líquida de reprodução $\left(\mathrm{R}_{\mathrm{o}}\right)$. O modelo Graus-dia proposto obteve uma precisão de um dia ou mais do que o valor observado, com erro máximo de $12,9 \%$. Concluiu-se que o modelo proposto é adequado para predizer a ocorrência de adultos no campo e que os parâmetros populacionais de $A$. craccivora em feijão-caupi são afetados negativamente durante o mês de novembro e positivamente em junho.

PALAVRAS-CHAVE: Aphis craccivora; Vigna unguiculata; ecologia de insetos; temperatura; constante térmica. 


\section{INTRODUCTION}

Cowpea [Vigna unguiculata (L.) Walp.] is a growing crop in Brazil that is experiencing changes in its cultivation; it was traditionally grown by family farmers in small areas with low-technology and is now being incorporated into soybean, rice, and maize cultivation, especially in the off-season, in large savanna areas with the use of modern technologies (NASCIMENTO, 2011).

The black cowpea aphid (Aphis craccivora Koch.) is considered the main pest associated with cowpea in Africa, Asia, and Latin America (SINGH; JACKAI, 1985; PETTERSSON et al., 1998), and can be found on all continents except Antarctica, causing losses in several countries (KAMPHUIS et al., 2012). According to OBOPILE (2006), the damage caused by this aphid results from it sucking the sap from leaves, stem, flowers, and pods, leading plants to shrink and to a delayed onset of flowering. Yield losses can be greater than 50\% when high infestations are not controlled.

A. craccivora has become more important for being a nonpersistent virus transmitter that infects cowpea by simple or mixed infection with cucumber mosaic virus (CMV) and cowpea aphid-born mosaic virus (CABMV) (OLIVEIRA et al., 2011), which can cause a reduction of $87 \%$ in production depending on the susceptibility of the cultivar, the virus strain, and environmental conditions (BASHIR et al., 2002).

Ecological pest management requires knowledge about the relationship between abiotic environmental factors and biotic variables associated with the pest and host. To that end, life tables and the thermal requirements of insects are often used in entomology (SILVEIRA NETO et al., 1976; CIVIDANES, 2003; CHEN et al., 2013).

The development of insects can be assessed by means of mathematical models that use temperature (CIVIDANES, 2003) according to the thermal constant " $K$ ", expressed in degree days (DD), to identify the developmental stage of a target insect, helping to elaborate strategies used in environmental pest management and detect the base temperature for development (Tb) in ${ }^{\circ} \mathrm{C}$ (HADDAD et al., 1999). Such models have proved to be effective in successfully predicting pests (CIVIDANES; CARVALHO, 2000; CIVIDANES, 2003; CIVIDANES; SOUZA, 2003).

In Brazil, little is known about the ecological relationships of the black cowpea aphid in cowpea. The use of life tables has been restricted to a selection of resistant varieties, and until recently, it was not possible to find data regarding the thermal requirements of this insect.

In Australia, BERG (1984) revealed that an increase in temperature resulted in an earlier onset of mortality and a decrease in the reproductive period of $A$. craccivora, regardless of the host plant species tested, estimating the $\mathrm{Tb}$ at $8.1^{\circ} \mathrm{C}$.

In Oklahoma, BERBERET et al. (2009) worked with $A$. craccivora in alfalfa (Medicago sativa $\mathrm{L}$.), under constant temperature conditions, and estimated its $\mathrm{Tb}$ at $7.1^{\circ} \mathrm{C}$ with a $\mathrm{K}$ of $100 \mathrm{DD}$. According to these authors, a rise in temperature decreased the longevity of adults and increased the number of nymphs produced per female per day.

Considering that temperatures rise above $39^{\circ} \mathrm{C}$ in Piauí at a given time of year and that the biology of an insect depends on its host and environmental conditions (ZHAOZHI et al., 2016), the objective with this study was to develop life and fertility tables for $A$. craccivora at different times of the year and, based on the thermal requirements of this species, predict the occurrence of adults under natural conditions.

\section{MATERIALS AND METHODS}

Aphis craccivora Koch. females were collected from cowpea plants grown at the Agricultural Sciences Center of the Federal University of Piauí, Teresina, Piauí, and transferred to cowpea plants, cultivar BR 17 Gurgueia, sown in $2.8 \mathrm{~L}$ pots that were exchanged fortnightly and kept in an air-conditioned room at $25^{\circ} \mathrm{C}$ under eight $\mathrm{T} 1040 \mathrm{~W}$ daylight fluorescent lamps and eight $40 \mathrm{~W}$ incandescent lamps to maintain the population of insects in the absence of predators.

Cowpea plants (BRS Tumucumaque) were sown in $2.8 \mathrm{~L}$ pots containing sandy soil, topsoil, and goat manure at a proportion of 4:1:0.5, fertilized with $5 \mathrm{~g}$ of NPK $(5: 30: 15)$ at the time of sowing, and irrigated manually with the aid of a watering can. These plants were kept on a metal bench approximately $60 \mathrm{~cm}$ above the ground in an open environment and covered to protect the insects from rainfall.

Twenty-eight days after sowing, 80 neonatal nymphs 0 to 13 hours old were individualized and placed in cages fixed to the abaxial side of a leaflet. These cages had $2.5 \mathrm{~cm}$ in diameter by $1.0 \mathrm{~cm}$ in height, made of clear plastic with one side sealed with voile fabric. A $4 \mathrm{~cm}$-diameter plastic disc containing a $0.5 \mathrm{~cm}$-thick sponge was used to fixate the cage to avoid damaging the leaf and to adapt to its imperfections, preventing the aphids from escaping. These cages were held by a plastic fastener and fixed with nylon thread so as not to damage the leaf petiole.

To obtain neonatal nymphs, 50 adult aphids were distributed in 25 cages as described above for 13 hours. Afterward, the adults were removed, and the newborn nymphs emerged, being then individualized and enumerated (adapted from BARBOSA et al., 2011).

The individualized nymphs were observed daily to collect data regarding the number of live and dead insects, developmental stage, onset and duration of the reproductive period, number of nymphs produced per female, and adult longevity. During the reproductive stage, the nymphs produced were counted and removed from the cages. In the nymphal phase, the 
nymphal stages and the nymphal period were determined by the presence of exuvia (adapted from BARBOSA et al., 2011).

We defined the onset of adulthood as the day of the fourth ecdysis, the pre-reproductive period as the time between the fourth ecdysis and the production of the first nymph, the reproductive period as the time during which nymphs were produced, and the post-reproductive period as the interval between the last birth and death. Longevity was quantified as the entire lifetime of adults.

This assay was repeated four times (November 2016 and March, April, and June 2017) in a completely randomized design, with treatments in November 2016 and March, April, and June 2017, with 80 replicates. The raw data for the observed parameters were transformed by $\sqrt{x+1}$ and statistically analyzed according to the F test and, when necessary, later by Tukey's test $(\mathrm{p}<0.05)$. We used Excel 2010 and Assistat 7.7 for statistical analysis.

Climatic data regarding maximum, minimum, and daily mean temperatures, monthly relative air humidity, and monthly rainfall were collected at the automatic meteorological station of the Federal University of Piauí, located approximately $500 \mathrm{~m}$ from where the experiments were performed.

Preliminarily, the thermal constant of development (K; $99 \mathrm{DDs})$, the lower developmental temperature $\left(\mathrm{Tb} ; 9.1^{\circ} \mathrm{C}\right)$, and the developmental rate equation $(y=0.0101 x-0.0922$ ¿ $)$ used for the estimates of accumulated degree days (ADDs) were determined in the laboratory according to HADDAD et al. (1999) at five constant temperatures: $18,22,25,28$, and $31^{\circ} \mathrm{C}$.

We estimated DD using the formula $D D=(\operatorname{Tmin}-T b)+\frac{\operatorname{Tmax}-\operatorname{Tmin}}{2}$, in which "Tmin" and "Tmax" are the minimum and maximum daily temperatures, respectively. The ADDs were determined according to the sum of the daily DDs up to the thermal constant K (CIVIDANES, 2003).

The percentage of error between the occurrence of adults predicted by the model and that observed in the field was estimated according to CIVIDANES (2003) using the formula $A D D=\frac{100^{*}(A d d-K)}{K}$, in which $\mathrm{ADD}$ represents the accumulated degree days and $\mathrm{K}$ indicates the thermal constant of $A$. craccivora.

We used the methodology by SILVEIRA NETO et al. (1976) to construct the life and fertility tables, determining the following variables: number or rate of survivors at the beginning of age $\mathrm{x}\left(\mathrm{L}_{\mathrm{x}}\right)$; number of individuals killed during the age range $x\left(d_{x}\right)$; age structure $\left(E_{x}\right)$, which corresponds to the number of individuals living between one day and the next; survival rate $\left(\mathrm{T}_{\mathrm{x}}\right)$, which represents the number of insects living beyond a certain age; life expectancy of individuals of age $\mathrm{x}\left(\mathrm{e}_{\mathrm{x}}\right)$; and probability of death at age $\mathrm{x}$ $\left(100 q_{x}\right)$, which indicates the probability of death occurring before the time established in $e_{x}$, as follows: $e_{x}=\dot{i}, e_{x}=T_{x} / L_{x}$, and $100 \mathrm{qx}=\left(\mathrm{d}_{\mathrm{x}} / \mathrm{L}_{\mathrm{x}}\right) \cdot 100$.

The values of the net reproductive rate $\left(\mathrm{R}_{0}\right)$, the time interval between generations $(T)$, and the innate capacity to increase in number $\left(\mathrm{r}_{\mathrm{m}}\right)$ were calculated with the values obtained in life and fertility tables $(\lambda)$ and the time needed for the population to double in terms of the number of individuals (TD), considering that $\left.\mathrm{R}_{0}=\Sigma\left(\mathrm{m}_{\mathrm{x}} \cdot \mathrm{l}_{\mathrm{x}}\right), \mathrm{T}=\mathrm{h}\left(\Sigma \mathrm{m}_{\mathrm{x}} \mathrm{l}_{\mathrm{x}}\right) / \Sigma \mathrm{m}_{\mathrm{x}} \mathrm{l}_{\mathrm{x}}\right)$, $\mathrm{r}_{\mathrm{m}}=\log \mathrm{R}_{0} / \mathrm{T} \cdot 0.4343, \lambda=\operatorname{anti} \log \left(\mathrm{r}_{\mathrm{m}} \cdot 0.4343\right)$, and, $\mathrm{TD}=\mathrm{L}_{\mathrm{n}}(2) / \mathrm{r}_{\mathrm{m}}$, in which $m_{x}=$ the number of females produced per female at age $x, 1_{x}=$ the survival rate at age $x$, and $m_{x} \cdot 1_{x}=$ the total number of females produced per female during the time interval.

We compared the survival curves obtained from the life table with the $\mathrm{G}$ test, taking into account the chi-square values at $0.1 \%$ probability.

The rates $\mathrm{R}_{0}, \mathrm{~T}, \mathrm{r}_{\mathrm{m}}, \lambda$, and TD were statistically analyzed using the jackknife method (MAIA et al., 2000).

\section{RESULTS AND DISCUSSION}

The time of year significantly affected the first and second developmental stages of black cowpea aphid, the nymphal and reproductive periods, longevity, the biological cycle, the number of nymphs produced per female, and the daily production of nymphs per female (Table 1).

We found a decrease in the developmental time between the first and second nymphal stages from November to June, as well as a shorter nymphal period over the different months. In contrast, a significant increase in longevity and nymph production per female was identified. This result might be due to the high temperatures recorded in November - a relatively warm and dry period of the year - and the warmer temperatures from March to June - the rainy season (Tables 1 and 2).

According to LAZZARI; CARVALHO (2013), the two extrinsic factors that influence the developmental period of aphids from birth to adulthood are food temperature and quality, while the two intrinsic factors are birth weight and shape (winged or not winged), with food quality affecting the birth weight and shape. Thus, insects on a poor diet are born smaller and have a longer nymphal stage.

Increased temperatures affect C3 plants, including cowpea. Very high temperatures, which occur in November, may increase photorespiration and decrease the photosynthetic rate due to the competition between $\mathrm{O}_{2}$ and $\mathrm{CO}_{2}$ for the binding site in the enzyme Rubisco (TAIZ; ZAIGER, 2013), which lowers the quality of plants for aphids. This might explain, in part, the longer nymphal period in November.

A second hypothesis could explain the fact that aphids experienced a longer nymphal stage in November. This hypothesis is based on the upper $\mathrm{Tb}$.

In general, the speed of development in insects is proportional to the increase in temperature; nevertheless, there is a limit. This limit, according to WILSON; BARNETT (1983), is the upper temperature threshold, or the temperature at which the developmental rate of an insect begins to decrease, which can 
cause a slight increase in the nymphal period (CIVIDANES, 2003). This suggests that the temperatures recorded during November exceed or are close to the upper thermal threshold of $A$. craccivora.

CHEN et al. (2013) studied A. craccivora at oscillating and constant temperatures in the laboratory and found that only $16 \%$ of the aphids maintained at a constant temperature of $35^{\circ} \mathrm{C}$ reached adulthood, but they did not reproduce. When kept at an oscillating temperature between 35 and $28.6^{\circ} \mathrm{C}$, only $65 \%$ reached adulthood, and they managed to produce some nymphs.

CIVIDANES (2003) identified an increase in the nymphal period of Brevicoryne brassicae under laboratory conditions when the insects were kept at $30^{\circ} \mathrm{C}$ compared to those maintained at lower temperatures. According to CIVIDANES (2003), this situation was due to the upper thermal limit of this aphid - between 27 and $30^{\circ} \mathrm{C}$.

ZHAOZHI et al. (2016) detected a linear decrease in the developmental period of $A$. craccivora at alternating temperatures of 24 and $30^{\circ} \mathrm{C}$ but observed that variations above $30^{\circ} \mathrm{C}$ increased the nymphal period of this aphid in both cotton and soybean.
These results support the hypothesis that aphids are constantly subjected to lethal and sublethal temperatures in November, which may have caused physiological disorders in the insects, increasing the nymphal period and decreasing the longevity and fertility of adults.

According to CHEN et al. (2013), aphids subjected to lethal and sublethal temperatures in tropical climates can recover from their effects if the insects spend enough time in the optimum temperature range; however, there are costs. This situation may have occurred during the experimental period in this study, considering that a maximum temperature of $39.4^{\circ} \mathrm{C}$ and a minimum temperature of $22.3^{\circ} \mathrm{C}$ were recorded during the nymphal period (Table 3); these costs are evidenced in parameters such as longevity and fertility (Tables 1 and 2).

The time of the year did not affect the pre- or post-reproductive period of $A$. craccivora, and at all tested times, the insects began to reproduce on the same day they became adults and continued reproducing until the last day of life (Table 1).

Adult longevity decreased by 7.4 days (68.5\%) and 2.8 days (45\%), respectively, when comparing June, March, and April (2017) to November (2016). We observed this same pattern

Table 1. Mean duration of developmental periods (days) and reproductive parameters of Aphis craccivora Koch. in cowpea under natural conditions. Teresina, Piauí, 2017.

\begin{tabular}{|c|c|c|c|c|c|}
\hline \multirow{2}{*}{ Biological Parameters } & \multicolumn{5}{|c|}{ Months } \\
\hline & November 2016 & March 2017 & April 2017 & June 2017 & CV\% \\
\hline $1 \mathrm{st}$ inst & $1.6 \pm 0.08 a$ & $1.5 \pm 0.06 a$ & $1.5 \pm 0.06 a$ & $1.2 \pm 0.05 b$ & 9.5 \\
\hline 2nd inst & $1.3 \pm 0.07 a$ & $1.1 \pm 0.04 b$ & $1.1 \pm 0.04 a b$ & $1.2 \pm 0.06 a b$ & 7.7 \\
\hline 3rd inst & $1.2 \pm 0.07 \mathrm{a}$ & $1.2 \pm 0.05 a$ & $1.1 \pm 0.04 \mathrm{a}$ & $1.1 \pm 0.03 a$ & 7.6 \\
\hline 4th inst & $1.5 \pm 0.08 a$ & $1.4 \pm 0.07 a$ & $1.3 \pm 0.06 a$ & $1.3 \pm 0.06 a$ & 9.5 \\
\hline Nymphal period & $5.7 \pm 0.14 a$ & $5.2 \pm 0.07 b$ & $5.0 \pm 0.06 b c$ & $4.8 \pm 0.06 c$ & 4.5 \\
\hline Pre-reproductive period & $0.1 \pm 0.07 a$ & $0.04 \pm 0.03 a$ & $0.03 \pm 0.02 \mathrm{a}$ & $0.04 \pm 0.03 a$ & 9.2 \\
\hline Reproductive period & $3.1 \pm 0.25 c$ & $6.10 \pm 0.49 b$ & $6.0 \pm 0.46 b$ & $10.5 \pm 0.52 \mathrm{a}$ & 24.8 \\
\hline Post-reproductive period & $0.2 \pm 0.08 \mathrm{a}$ & $0.15 \pm 0.06 a$ & $0.12 \pm 0.05 a$ & $0.3 \pm 0.07 a$ & 16.5 \\
\hline Longevity & $3.4 \pm 0.24 c$ & $6.2 \pm 0.5 b$ & $6.2 \pm 0.47 b$ & $10.8 \pm 0.56 a$ & 25.0 \\
\hline Nymphs produced per females & $16.7 \pm 1.6 \mathrm{c}$ & $43.7 \pm 4.3 b$ & $43.7 \pm 4.04 b$ & $99.0 \pm 21.9 a$ & 42.9 \\
\hline Nymphs produced/female/day & $4.9 \pm 0.38 b$ & $6.4 \pm 0.36 a b$ & $6.4 \pm 0.34 a b$ & $9.7 \pm 2.18 \mathrm{a}$ & 28.2 \\
\hline Biological cycle & $9.1 \pm 0.26 c$ & $11.4 \pm 0.49 b$ & $11.0 \pm 0.46 b c$ & $15.6 \pm 0.55 a$ & 14.2 \\
\hline
\end{tabular}

Means followed by the same letter within a row did not differ statistically according to Tukey's test $(p<0.05)$; CV\%: coefficient of variation.

Table 2. Mean monthly temperature, relative humidity, and precipitation data recorded at an automatic meteorological station in the city of Teresina, Piauí, 2017.

\begin{tabular}{|ccccccc}
\multirow{2}{*}{ Year } & Month & \multicolumn{3}{c}{ Air temperature $\left({ }^{\circ} \mathrm{C}\right)$} & & \multicolumn{2}{c}{ Relative humidity (\%) } & Precipitation (mm) \\
\cline { 3 - 7 } & November & 38.7 & 30.5 & 23.9 & 51 & 8 \\
\hline 2016 & March & 32.8 & 26.1 & 22.4 & 84 & 415.8 \\
\hline & April & 33 & 26.5 & 22.7 & 83 & 260.2 \\
\hline & June & 33 & 26.5 & 21.5 & 74 & 6.8 \\
\hline
\end{tabular}


in the daily production of nymphs per females, total production of nymphs, and biological cycle (Table 1).

ZHAOZHI et al. (2016) studied the effects of host type and temperature on $A$. craccivora and found that adult longevity significantly decreased with increasing temperatures when the aphids were reared in cotton but remained the same when they were maintained in soybean. This result suggests that the host type also influences the response of the aphid when subjected to thermal stress. Similarly, CHEN et al. (2013) identified reduced longevity in A. craccivora maintained on $V$. unguiculata sesquipedalis when the insects were subjected to high temperatures, corroborating the results presented in this study.

Regarding the total number of nymphs produced per female, the amplitude of variation was much higher than that of the daily fecundity, with 82.3 nymphs $(83.1 \%)$ produced between June and November and 27 nymphs (61.7\%) produced in March, April, and November (Table 1). ZHAOZHI et al. (2016) also reported the reduction in fecundity of $A$. craccivora with increasing temperatures in association with two hosts, soybean and cotton. When the aphids were maintained in cotton, the decrease was drastic: 50 nymphs/female at alternating temperatures of 24 and $30^{\circ} \mathrm{C}$ to 23 nymphs/female when the temperature varied between 24 and $36^{\circ} \mathrm{C}$.

The daily production of nymphs per female in November was significantly different from the one in June but statistically equal to those in March and April. With respect to June, the reduction was of 4.8 nymphs per day per female ( $49.4 \%)$. As to March and April, the decrease was of 23.9\% (1.5 nymphs/ female/day) (Table 1). It is possible that the instinct for survival under adverse conditions directs the life energy for reproduction since $A$. craccivora has a short period of life, and, in theory, the adverse conditions to which an adult is subjected should improve. In this case, decreasing the total amount of offspring and maintaining the daily production of nymphs under low longevity is more favorable during this critical period, confirming the results from WARD; DIXON (1982), which state that some species are flexible in their reproductive capacity and may, under conditions of nutritional stress, undergo the reabsorption of embryos and sacrifice their total fecundity potential to maintain their immediate reproductive rate and their survival over a short term.

The biological cycle of the insects was also influenced by the time of year. There was a reduction of 6.5 days (41.6\%) between November and June, of 2.3 days (20.1\%) between November and March, and of 1.9 days (17.2\%) between November and April (Table 1). The decrease in the full cycle can be explained by the great reduction in the longevity of adults when subjected to the high temperatures of November, even if these temperatures slightly increased the nymphal period.

Relative air humidity and rainfall might also have influenced the biological data of the black cowpea aphid as mean temperatures remain practically constant between March and June (Table 2). During March and April, when relative humidity and precipitation are high, biological data had improved compared to November but remained almost constant between these two months. However, when the relative air humidity is low, the rains almost completely cease, but the mean temperatures remain constant in comparison to June. The biological data of the aphid improve even more with the reduction in the rainfall period, resulting in increased longevity and specific and total fertility of the population.

$\mathrm{R}_{0}$ significantly increased from November 2016 to June 2017 due to the better environmental conditions (Table 3). $R_{0}$ is the sum of the products of the survival rate at age $\mathrm{x}$ and the specific fertility at age $x$. Thus, the low population growth rate in November resulted from the few individuals who entered the reproductive age $(\mathrm{n}=35)$, as well as the decrease in the total nymphs produced per female due to the reduced longevity of adults. The number of nymphs produced per female per day was statistically the same between November and March and between November and April (Table 1).

CHEN et al. (2013) also found a linear reduction in $\mathrm{R}_{0}$ when they studied $A$. craccivora in $V$. unguiculata sesquipedalis at constant temperatures of $28.6,30$, and $32.5^{\circ} \mathrm{C}$ and in alternating temperature regimes of 28.6-30.0, 28.632.5 , and $28.6-35.5^{\circ} \mathrm{C}$. This decrease was approximately 80 to 10 in both thermal regimes. The values are very close to those presented in this study.

Table 3. Demographic parameters of Aphis craccivora in cowpea under "natural” conditions at four times of the year. Teresina, Piauí, 2017.

\begin{tabular}{lcccc} 
Biological & \multicolumn{4}{c}{ Months* } \\
Parameters & November $2016(\mathbf{n = 3 5 )}$ & March $2017(\mathbf{n = 5 3 )}$ & April $2017(\mathbf{n = 6 0})$ & June 2017 ( $\mathbf{n = 5 6 )}$ \\
\hline $\mathrm{R}_{0}$ & $13.2 \pm 0.38 \mathrm{c}$ & $26.8 \pm 0.72 \mathrm{a}$ & $28.9 \pm 0.68 \mathrm{a}$ & $90.44 \pm 2.3 \mathrm{~b}$ \\
\hline $\mathrm{T}$ & $7.19 \pm 0.20 \mathrm{a}$ & $7.97 \pm 0.21 \mathrm{a}$ & $7.53 \pm 0.17 \mathrm{a}$ & $8.10 \pm 0.2 \mathrm{a}$ \\
\hline $\mathrm{r}_{\mathrm{m}}$ & $0.36 \pm 0.01 \mathrm{a}$ & $0.41 \pm 0.01 \mathrm{a}$ & $0.44 \pm 0.01 \mathrm{a}$ & $0.55 \pm 0.01 \mathrm{a}$ \\
\hline$\lambda$ & $1.43 \pm 0.04 \mathrm{a}$ & $1.51 \pm 0.04 \mathrm{a}$ & $1.56 \pm 0.03 \mathrm{a}$ & $1.74 \pm 0.04 \mathrm{a}$ \\
\hline $\mathrm{TD}$ & $1.93 \pm 0.05 \mathrm{a}$ & $1.67 \pm 0.04 \mathrm{a}$ & $1.55 \pm 0.03 \mathrm{a}$ & $1.24 \pm 0.03 \mathrm{a}$ \\
\hline
\end{tabular}

*Mean temperature $\left({ }^{\circ} \mathrm{C}\right)$ : November -30.5 ; March - 26.1; April and June - 26.5; $\mathrm{R}_{\mathrm{o}}$ : net reproductive rate; $\mathrm{T}$ : mean period of a generation; $r_{m}$ : inability to increase in number; $\lambda$ : finite increase rate; TD: time for the population to double.

Means with the same letter within a row are not significantly different according to Student's $t$ test $(p<0.05)$. 
ZHAOZHI et al. (2016) identified significant reductions in $\mathrm{R}_{0}$ when they subjected $A$. craccivora to several thermal regimes of alternating temperatures in two different hosts: soy and cotton. In soybean, $\mathrm{R}_{0}$ ranged from 61.7 to 78.8 in the thermal regimes of $24-36^{\circ} \mathrm{C}$ and $24-32^{\circ} \mathrm{C}$, respectively. In cotton, this variation was $45.3\left(24-30^{\circ} \mathrm{C}\right)$ and $9.3\left(24-36^{\circ} \mathrm{C}\right)$.

Although no significant differences were found in the other life table parameters, a linear trend in the data could be observed in all cases except the mean period of one generation $(\mathrm{T})$, which fluctuated among the studied months, being higher in June (mild temperatures) and lower in November (higher temperatures).

The generation time is calculated with the formula $T=\frac{\sum m_{x} \cdot l_{x} x}{\sum m_{x} l_{x}}$; thus, a longer longevity (number of years of age) of reproducing individuals indicates a longer time between generations. As the increase in temperature reduced the longevity of females, $\mathrm{T}$ consequently declined. In this case, the longevity was approximately three times greater in June than in November.

Several factors can influence the resistance to high temperatures, including the pattern of temperature fluctuations, genetic lineage, stage of life history, acclimatization, and bacterial symbionts (BOWLER; TERBLANCHE, 2008; PUCHERELLI et al., 2012). Considering that CHEN et al. (2013) worked with aphids collected in Taichung, Taiwan, and ZHAOZHI et al. (2016) studied aphids collected in Xinjiang, China, it is possible that there are differences between the populations of $A$. craccivora tested by these authors and the population investigated in this study, mainly regarding genetic lineage, acclimatization, and bacterial symbionts.

We found a positive linear relationship for $\mathrm{r}_{\mathrm{m}}$ and $\lambda$ in the studied months and a negative one for TD. Furthermore, in June, TD took the least amount of time, and the population growth rate $\left(\mathrm{r}_{\mathrm{m}}\right)$ was the highest, demonstrating that this time of the year has the greatest potential for $A$. craccivora to reach large population peaks over a shorter time interval; therefore, more careful observations regarding the presence of this aphid in the growing area are necessary.

The results found by CHEN et al. (2013) and ZHAOZHI et al. (2016) corroborate those presented in this study, in which $\mathrm{r}_{\mathrm{m}}$ was linearly reduced by more than two times under increasing temperatures.

At all tested times, the survival curve of $A$. craccivora in cowpea was type I, which indicates that the mortality rate was highest among adult individuals (Fig. 1).

Statistically, all survival curves were different from each other when compared in pairs by the $\mathrm{G}$ test at the $0.1 \%$ significance level. This result suggests that the environment significantly interfered with the survival of the individuals in the studied periods (Table 4).
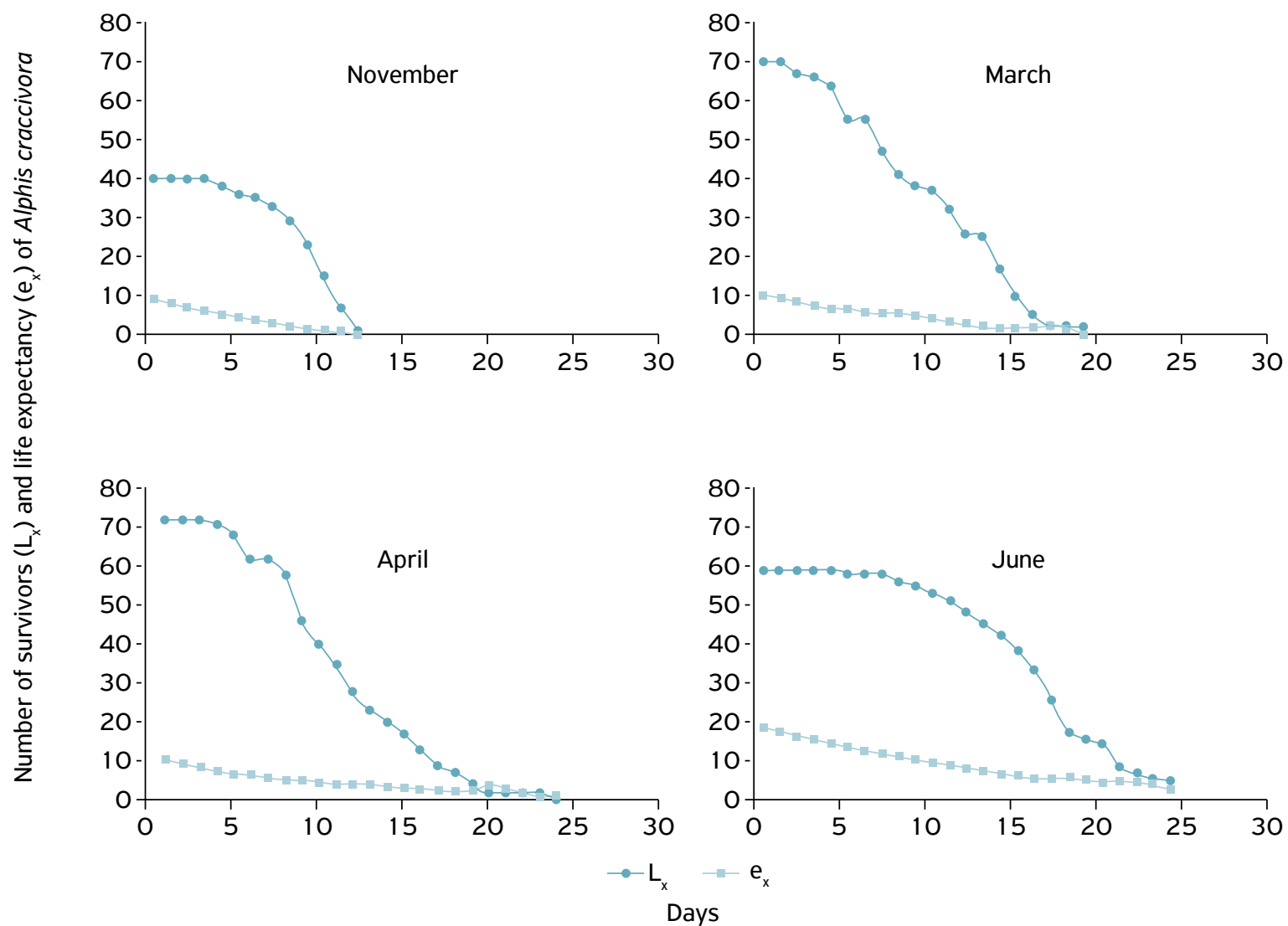

Figure 1. Survival $\left(\mathrm{L}_{\mathrm{x}}\right)$ and life expectancy $\left(\mathrm{e}_{\mathrm{x}}\right)$ of Aphis craccivora in cowpea under "natural" conditions. Teresina, Piauí, 2017. 
With improved climatic conditions, the life expectancy $\left(\mathrm{e}_{\mathrm{x}}\right)$ at birth of aphids increased from 8.9 days in November to 9.94 days in March, 10.44 days in April, and 15.88 days in June.

The period over which $50 \%$ of the population died increased with the improvement of environmental conditions. In November, $50 \%$ of the population died between 9 and 10 days, and the probability of death $\left(100 q_{x}\right)$ was $53 \%$ on day 10 , with a life expectancy $\left(\mathrm{e}_{\mathrm{x}}\right)$ of 1.03 days. On average, $50 \%$ mortality occurred between the ages of 10.5 and 11.5 days, with a $100 q_{x}$ value of $18 \%$ and an $e_{x}$ value of 3.28 days for individuals aged 11.5 days. In April, we identified a

Table 4. Values calculated using the $G$ test to compare survival curves.

\begin{tabular}{lccc} 
Combinations of times & G value & $\chi^{2}$ & Significance \% \\
\hline November - March & 81.4 & 10.83 & 0.1 \\
\hline November - April & 83.3 & 10.83 & \\
\hline November - June & 243.3 & 10.83 & \\
\hline March - April & 16.6 & 10.83 & \\
\hline March - June & 125.5 & 10.83 & \\
\hline April - June & 96.5 & 10.83 & \\
\hline
\end{tabular}

$50 \%$ mortality in the age range 10.5 to 11.5 days, with a $100 \mathrm{q}_{\mathrm{x}}$ value of $17.8 \%$ and an $\mathrm{e}_{\mathrm{x}}$ value of 4 days for individuals aged 11.5 days. In June, it took 17.5 days for $50 \%$ mortality to occur, with a life expectancy of 2.8 days and a $34.7 \%$ probability of death (Fig. 1).

The production of nymphs in all studied periods began in the same age group - between 4.5 and 5.5 days - , but with different intensities. In November, the production of nymphs started with 2.2 nymphs per female and reached the peak of production on the second day of breeding ( 6.5 days), with a mean of 5.2 nymphs per female. In March and April, the peak occurred on the first day of breeding (5.5 days), with means of 7.3 and 8.7 nymphs per female, respectively. In June, reproduction started at 4.5 days with 2.7 nymphs per female, with an apex on the third day of reproduction, reaching 31.4 nymphs per female (Fig. 2).

The model used to predict the occurrence of adult aphids reached an accuracy of one to more or fewer days, with a maximum error of $12.9 \%$ (Table 5 ).

According to DILLON et al. (2010), within the range of suitable temperatures below the optimum, as the temperature increases, so do metabolic rates, which leads to faster development rates. Thus, during November, the maximum

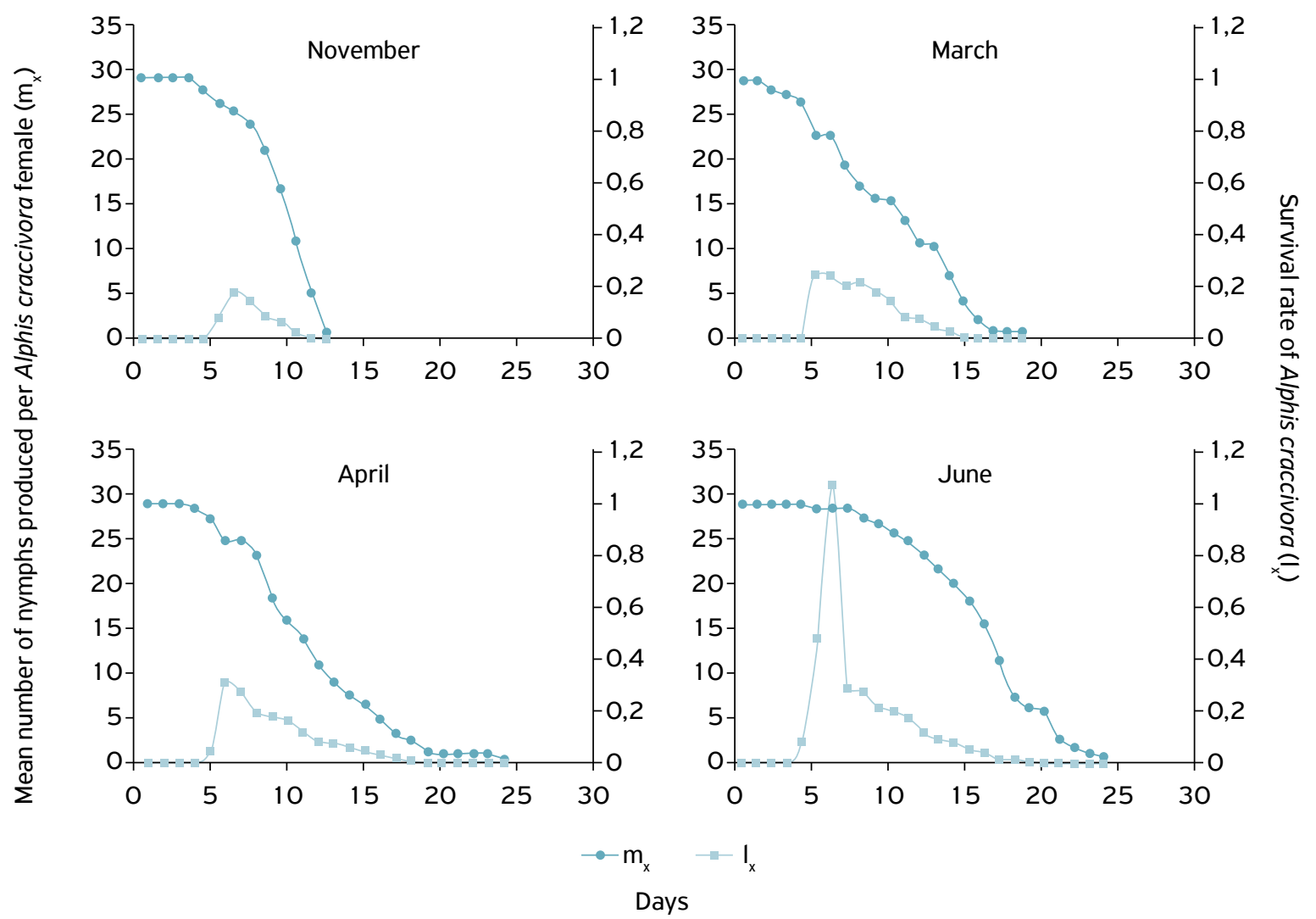

Figure 2. Mean number of nymphs produced/female $\left(m_{\mathrm{x}}\right)$ and survival rate $\left(1_{\mathrm{x}}\right)$ of Aphis craccivora in cowpea under "natural" conditions. Teresina, Piauí, 2017. 
temperatures exceeded the optimum development range, likely reaching lethal or sublethal temperatures, which interfered with the development of the aphid, acting in an opposite way than expected. Therefore, we used the model generated in the laboratory, under constant temperatures, to predict the occurrence of adults.

HIGLEY et al. (1986) suggested that the use of a DD model that provides estimates with 10 to $15 \%$ accuracy could be appropriate for pest management programs, with a slightly higher accuracy necessary for use in population dynamics studies. Consequently, the proposed model is suitable for both situations.

CIVIDANES (2003) developed two DD models to predict the occurrence of adults of Brevicoryne brassicae, one constructed with laboratory data and one constructed with field data, and noted that the laboratory model was more accurate, reaching a maximum error of $14.5 \%$.

Likewise, CIVIDANES; SOUZA (2003) used a DD model prepared in laboratory to predict the occurrence of adults of Myzus persicae in cabbage fields and found

Table 5. Developmental periods of black cowpea aphids from birth to adulthood based on their thermal requirements considering the lower base temperature of $9.13^{\circ} \mathrm{C}$ and the thermal constant of 99 degree days, as obtained in the laboratory. Teresina, Piauí, 2017.

\begin{tabular}{|c|c|c|c|c|c|c|c|c|}
\hline \multicolumn{8}{|c|}{ November } & \multirow{2}{*}{$\begin{array}{c}\text { Erro } \\
\%\end{array}$} \\
\hline Days/month & Mean days & Minimum & Maximum & DD & ADD & DP calculated days** & DP observed days & \\
\hline 1 & 30.0 & 22.3 & 39.0 & 21.52 & 21.52 & 4.7 & 5.7 & 12.1 \\
\hline 2 & 30.2 & 25.2 & 39.4 & 23.17 & 44.69 & & & \\
\hline 3 & 29.5 & 24.0 & 37.6 & 21.67 & 66.36 & & & \\
\hline 4 & 30.7 & 24.2 & 38.4 & 22.17 & 88.53 & & & \\
\hline 5 & 30.0 & 24.3 & 38.8 & 22.42 & 110.95 & & & \\
\hline Mean & 30.1 & 24.0 & 38.6 & & & & & \\
\hline \multicolumn{9}{|l|}{ March } \\
\hline 1 & 25.8 & 22.8 & 31.1 & 17.82 & 17.82 & 5.6 & 5.2 & 12.9 \\
\hline 2 & 25.8 & 22.8 & 32.4 & 18.47 & 36.29 & & & \\
\hline 3 & 26.7 & 22.2 & 33.5 & 18.72 & 55.01 & & & \\
\hline 4 & 27.4 & 22.0 & 34.3 & 19.02 & 74.03 & & & \\
\hline 5 & 27.2 & 21.8 & 34.2 & 18.87 & 92.9 & & & \\
\hline 6 th & 27.3 & 22.3 & 33.8 & 18.92 & 111.82 & & & \\
\hline Mean & 26.7 & 22.3 & 33.2 & & & & & \\
\hline \multicolumn{9}{|l|}{ April } \\
\hline 1 & 26.2 & 22.0 & 31.1 & 17.42 & 17.42 & 5.6 & 5.0 & 12.4 \\
\hline 2 & 26.8 & 22.9 & 32.8 & 18.72 & 36.14 & & & \\
\hline 3 & 27.4 & 23.4 & 33.1 & 19.12 & 55.26 & & & \\
\hline 4 & 27.5 & 22.0 & 33.1 & 18.42 & 73.68 & & & \\
\hline 5 & 27.0 & 23.2 & 33.3 & 19.12 & 92.8 & & & \\
\hline 6 th & 25.7 & 23.1 & 32.1 & 18.47 & 111.27 & & & \\
\hline Mean & 26.8 & 22.8 & 32.6 & & & & & \\
\hline \multicolumn{9}{|l|}{ June } \\
\hline 1 & 26.6 & 22.6 & 32.1 & 18.22 & 18.22 & 5.7 & 4.8 & 7.3 \\
\hline 2 & 26.2 & 20.3 & 32.6 & 17.32 & 35.54 & & & \\
\hline 3 & 26.0 & 19.7 & 32.4 & 16.92 & 52.46 & & & \\
\hline 4 & 26.3 & 20.6 & 32.6 & 17.47 & 69.93 & & & \\
\hline 5 & 26.9 & 20.1 & 33.9 & 17.87 & 87.8 & & & \\
\hline 6 th & 26.9 & 21.7 & 33.4 & 18.42 & 106.22 & & & \\
\hline Mean & 26.5 & 20.8 & 32.8 & & & & & \\
\hline
\end{tabular}

*We used the development rate equation obtained in the laboratory tests at $18,22,25,28$, and $31^{\circ} \mathrm{C}$; * ${ }^{*} \mathrm{DP}=\mathrm{K} /(\mathrm{T}-\mathrm{Tb})$; DD: degree days; DP: developmental period; $\mathrm{K}$ : thermal constant; $\mathrm{T}$ : mean ambient temperature; Tb: lower base temperature. 
the same accuracy presented in this study, with a difference of one to more or fewer days and an average error of $15 \%$.

In addition to temperature, other factors may have influenced the development of the aphids. In Teresina, November is a hot, dry month with little wind; March and April are rainy and muggy months, with high relative humidity and low wind. June has good relative humidity, regular winds, and milder temperatures, making the thermal conditions better than the ones mentioned above, a fact that potentially resulted in ideal conditions for the population growth of $A$. craccivora (Table 5).

\section{CONCLUSIONS}

November in Teresina, Piauí, presents unfavorable climatic conditions for the development, survival, and reproduction of $A$. craccivora.

June, due to a better thermal scenario, provides the best environmental circumstances for the development of $A$. craccivora in cowpea, increasing the $\mathrm{R}_{0}$.

The proposed DD model is adequate to predict the occurrence of adults of $A$. craccivora in cowpea.

Relative air humidity and the presence of winds influence the environmental parameters of $A$. craccivora, but these effects require further studies.

| | | | | | | | | | | | | | | | | | | | | | | | | | | | | | | | | | | | | | | | | | | | | | | | | | | | | | | | | | | | | | | | | | | | | | | | | | | | | | | | | | | | | | | | | | | | | | | | | | | | | | | | | | | | | | | | | | | | | | | | | | | | | | | | | | | | | | | | | | | | | | | | | | | | | | | | | | | | | | | | | | | | | | | | | | | | | | | | | | | | | | | | | | | | | | | | | | | | | | | | | | | REFERENCES

BARBOSA, L.R.; CARVALHO, C.F.; AUAD, A.M.; SOUZA, B..; BATISTA, E.S.P. Tabelas de esperança de vida e fertilidade de Myzus persicae sobre pimentão em laboratório e casa de vegetação. Bragantia, Campinas, v.70, n.2, p.375-382, 2011 . http://dx.doi. org/10.1590/S0006-87052011000200018

BASHIR, M.; AHMAD, Z.; GHAFOOH, A. Cowpea aphidborne potyvirus: a review. International Journal of Pest Management, v.48, n.2, p.155-168, 2002. http://dx.doi. org/10.1080/09670870110118722

BERBERET, R.C.; GILES, K.L.; ZARRABI, A.A.; PAYTON, M.E. Development, reproduction, and within-plant infestation patterns of Aphis craccivora (Homoptera: Aphididae) on alfalfa. Environmental Entomology, v.38, n.6, p.1765-1771, 2009. https://doi. org/10.1603/022.038.0630

BERG, G.N. The effect of temperature and host species on the population growth potential of the cowpea aphid, Aphis craccivora Koch (Homoptera: Aphididae). Australian Journal of Zoology, v.32, n.3, p.345-352, 1984. https://doi.org/10.1071/ Z09840345

BOWLER, K.; TERBLANCHE, J.S. Insect thermal tolerance: what is the role of ontogeny, ageing and senescence? Biological Reviews of the Cambridge Philosophical Society, v.83, n.3, p.339-355, 2008.

CIVIDANES, F.J. Uso de graus-dia em entomologia, com particular referência ao percevejo da soja. Jaboticabal: Funep, 2000. $31 \mathrm{p}$.

CIVIDANES, F.J. Exigências térmicas de Brevicoryne brassicae e previsão de picos populacionais. Pesquisa Agropecuária Brasileira, Brasília, v.38, n.5, p.561-566, 2003.

CIVIDANES, F.J.; CARVALHO, D.R. Uso de graus-dia para a previsão de ocorrência de ninfas e adultos de Piezodorus guildinii (West.) (Heteroptera: Pentatomidae) em soja. Anais da Sociedade Entomológica do Brasil, v.29, n.2, p.269-275, 2000. http:// dx.doi.org/10.1590/S0301-80592000000200008
CIVIDANES, F.J.; SOUZA, V. P. Exigências térmicas e tabelas de vida de fertilidade de Myzus persicae (Sulzer) (Hemiptera: Aphididae) em laboratório. Neotropical Entomology, v.32, n.3, p.413-419, 2003. http://dx.doi.org/10.1590/S1519-566X2003000300005

CHEN, C.Y.; CHIU, M.C.; KUO, M.H. Effect of warming with temperature oscillations on a low-latitude aphid, Aphis craccivora. Bulletin of Entomological Research, v.1, n.103, p.406-413, 2013. https:// doi.org/10.1017/S0007485312000867

DILLON, M.E.; WANG, G.; HUEY, R.B. Global metabolic impacts of recent climate warming. Nature, v.467, n. 7316, p.704-706, 2010. https://doi.org/10.1038/nature09407

HADDAD, M.L.; PARRA, J.R.P.; MORAES, R.C.B. Métodos para estimar os limites térmicos inferior e superior de desenvolvimento de insetos. Piracicaba, FEALQ, 1999. 29p.

HIGLEY, L.G.; PEDIGO, L.P.; OSTLIE, K.R. Degday: a program for calculating degree-days, and assumption behind the degree-day approach. Environmental Entomology, v.15, n.5, p.999-1016, 1986. https://doi.org/10.1093/ee/15.5.999

KAMPHUIS, L.G.; GAO, L.; SINGH, K.B. Identification and characterization of resistance to cowpea aphid (Aphis craccivora Koch) in Medicago truncatula. BMC Plant Biology, v.12, n.1, p.101, 2012. https://doi.org/10.1 186/1471-2229-12-101

LAZZARI, S.M.N.; CARVALHO, R.C.Z. Sugadores de seiva (Aphidoidae). In: PANIZZI, A.R.; PARRA, J.R.P. Bioecologia e nutrição de insetos. Bases para o manejo integrado de pragas. Brasília: Embrapa, 2013. p.1735-1902.

MAIA, A.H.N.; LUIZ, A.J.B.; CAMPANHOLA, C. Statistical inference on associated fertility life parameters using jackknife technique: computational aspects. Journal of Economic Entomology, v.93, n.2, p.511-518,2000.http://dx.doi.org/10.1603/0022-0493-93.2.511

NASCIMENTO, H.T.S. Apresentação. In: FREIRE FILHO, F.R.; RIBEIRO, V.Q.; ROCHA, M.M.; SILVA, K.J.D.; NOGUEIRA, M.S.R.; RODRIGUES, E.V. Feijão-caupi no Brasil: produção, melhoramento genético, avanços e desafios. Teresina: Embrapa Meio-Norte, 2011. 
OBOPILE, M. Economic threshold and injury levels for control of cowpea aphid, Aphis craccivora Linnaeus (Homoptera: Aphididae) on cowpea. African Plant Protection, v. 12, p.111-115, 2006.

OLIVEIRA, C.R.R. Reação de genótipos de feijão-caupi às coinfecções pelo Cucumber mosaic virus, Cowpea aphid-borne mosaic virus e Cowpea severe mosaic vírus. $89 \mathrm{f}$. Dissertação (Mestrado em Genética e Melhoramento) - Universidade Federal do Piauí, Teresina, 2011.

PETTERSSON, J.; KARUNARATNE, S.; AHMED, E.; KUMAR, V. The cowpea aphid, Aphis craccivora, host plant odours and pheromones. Entomologia Experimentalis et Applicata, v.88, n.2, p.177-184, 1998. https://doi.org/10.1046/j.1570-7458.1998.00360.x

PUCHERELLI, S.F.; PEAIRS, F.B.; MERRILL, S.C.; RANDOLPH, T.L. Russian wheat aphid (Hemiptera: Aphididae) reproduction and development on five noncultivated grass hosts. Arthropod-Plant Interactions, v.6, n.1, p.67-73, 2012. https://doi.org/10.1007/ s1 1829-011-9152-5

SILVEIRA NETO, S.; NAKANO, O.; BALDIN, D.; VILLANOVA, N.A. Manual de ecologia dos insetos. São Paulo: Agronômica Ceres, 1976.419p.
SINGH, S.R.; JACKAI, L.E.N. Insect pests of cowpea in Africa: their life cycle, economic importance, and potential for control. In: SINGH, S.R.; RACHIE, R.O. (Eds.). Cowpea research, production, and utilization. Chichester, United Kingdom: John Wiley and Sons, 1985. p.217-231.

TAIZ, L.; ZEIGER, E. Fisiologia vegetal. 5. ed. Porto Alegre: Artmed, 2013. $918 p$.

WILSON, L.T.; BARNETT, W.W. Degree-days: an aid in crop and pest management. California Agriculture, v.37, n. 1/2, p.4-7, 1983.

WARD, S.A.; DIXON, A.F.G. Selective resorption of aphid embryos and habitat changes relatives to life-span. The Journal of Ecology, Oxford, v.51, p.854-864, 1982.

ZHAOZHI, L.; LIKAI, F.; GUIZHEN, G.; LING-LING, G.; HAN, P.; SHARMA, S.; ZALUCKI, M. P. Differences in the high-temperature tolerance of Aphis craccivora (Hemiptera: Aphididae) on cotton and soybean: implications for ecological niche switching among hosts. The Japanese Society of Applied Entomology and Zoology, v.52, n.1, p.9-18, 2016. https://doi.org/10.1007/ s13355-016-0446-z 